\title{
MTM - podstawa do optymalizacji procesów logistycznych
}

http://dx.doi.org/10.18778/8142-085-3.06

Monika Kujawa, Dawid Mikła

Wydział Ekonomiczno-Socjologiczny, Uniwersytet Łódzki

\section{Wstęp}

Dzisiejszy sektor usług jest przepełniony konkurencją i to ona zmusza przedsiębiorstwa do walki o poprawę swoich wyników ostatecznych, czyli ceny czy jakości produktu skierowanego do odbiorcy. Pokazuje to doskonale, że myśląc długookresowo, firma musi wykorzystywać CPU i optymalizować poszczególne procesy do osiągnięcia pożądanego przez klienta wyniku. Koncepcja Lean Manufacturing wykorzystuje ideę tak zwanego odchudzonego myślenia, gdzie dąży się do eliminacji wszelkiego rodzaju marnotrawstwa (jap. - muda). Zaoszczędzone w konkretnych procesach zasoby możemy wykorzystać w innych segmentach działalności przedsiębiorstwa. Pozwala to na zwiększenie produktywności i poprawę jakości pracy. Istotą Lean Management jest uzyskanie jak największej produktywności przy sprawnej organizacji i wysokiej jakości. Dla uzyskania wyżej wymienionych założeń konieczne jest stałe doskonalenie organizacji pracy i odpowiednie wyszkolenie pracowników. Wyróżniamy siedem podstawowych rodzajów muda w działalności produkcyjnej:

- nadprodukcję,

- zbędne zapasy,

- zbędne przetwarzanie,

- przestoje produkcyjne,

- braki produkcyjne,

- nadmierny transport,

- zbędny ruch na stanowisku pracy.

Odwołując się do ostatniego punktu, należy wskazać duże znaczenie identyfikacji strumienia wartości dla każdego produktu. Składowe czynności procesu należy podzielić na:

- mające wartość dodaną dla klienta w sposób bezpośredni,

- mające wartość dodaną dla klienta w sposób pośredni,

- zbędne. 
Value stream (pol. strumień wartości) w terminologii Lean zakłada eliminację ostatniego z wyżej wymienionych punktów i maksymalne wyeliminowanie marnotrawstwa $\mathrm{z}$ dwóch pierwszych, aby proces i związana $\mathrm{z}$ nim informacja nie były niczym zakłócone. Jednym z narzędzi, które mogą zostać wykorzystane w usprawnianiu strumienia wartości, jest MTM (Methods Time Measurement - Metody pomiaru czasu), która w połączeniu z takimi elementami, jak: mapowanie procesów, Poka Yoke, Kaizen czy nowoczesnymi symulacjami komputerowymi, pozwala na minimalizowanie kosztów procesu.

\section{Standaryzacja procesów logistycznych}

Proces logistyczny jest zorganizowanym ciągiem następujących po sobie działań, w wyniku którego możliwa jest realizacja przepływu nabytych przez produkcję i dystrybucję surowców, tak by końcowy odbiorca otrzymał ostateczny produkt, wyrób lub usługę. Efektywność procesu logistycznego w znacznym stopniu zależna jest od struktury techniczno-organizacyjnej przedsiębiorstwa. Z punktu widzenia produktywności procesów logistycznych bardzo ważna jest architektura czasowo-przestrzenna procesów technologicznych, ich układ i wzajemne połączenia, a ich sprawność jest miarą efektywności przedsiębiorstwa. Standard oznacza przeciętną normę, przeciętny typ, model, wyrób odpowiadający określonym wymogom, wzorzec. Standaryzacja procesów logistycznych jest elementem pozwalającym na ciągłe podnoszenie poziomu konkurencyjności przedsiębiorstwa poprzez stałe doskonalenie jakości wyrobów i usług dzięki wykorzystywaniu uznanych reguł technicznych. Stosowanie sprawdzonych rozwiązań gwarantuje poprawę bezpieczeństwa personelu i otoczenia przedsiębiorstwa. Prosty opis procesu pozwala na jego odpowiednie poznanie oraz interpretację przez organy o niskiej kompetencji. Standaryzacja jest fundamentem zasad Lean Management. Skupia się ona na poszukiwaniu optymalnej metody wykonania czynności na danym stanowisku pracy. Umożliwia redukcję błędów powodowanych przez wysoki stopień dowolności w procesie. Wprowadzenie standardu pracy w procesie logistycznym redukuje zmienność związaną z brakiem powtarzalności oraz daje możliwość wykorzystania zdobytego doświadczenia, pozwalającego wystrzegać się błędów. Pomocny w minimalizacji błędów w projektowaniu procesu jest diagram Ishikawy, przedstawiający pięć kategorii przyczyn, przy wykorzystaniu których możemy wypracować optymalne rozwiązanie problemu.

Kategoriami wymienionymi w diagramie Ishikawy są:

- maszyny i urządzenia - czyli standardy mające na celu ograniczenie negatywnych oddziaływań czynników na przebieg procesów związanych na przykład z awariami lub błędną obsługą maszyny, 
- materiały - czyli standardy mające na celu ograniczenie niekorzystnej zmienności właściwości materiału wskutek nieprawidłowego przechowywania lub transportu,

- otoczenie - czyli standardy postępowania, które ograniczają negatywne oddziaływanie środowiska naturalnego na funkcjonowanie ludzi i maszyn, oraz przechowywania lub transportowania materiałów czy produktów gotowych,

- człowiek - czyli wzorce postępowania mające na celu ograniczenie chaosu wprowadzanego przez człowieka,

- metoda - jest to celowo i logicznie stosowany model postępowania dążący do osiągnięcia określonego celu. Metoda jest integratorem wyżej wymienionych kategorii przyczyn, a jej błędny dobór, jak i jej nieprecyzyjna parametryzacja, prowadzą do wystąpienia zakłóceń w procesie.

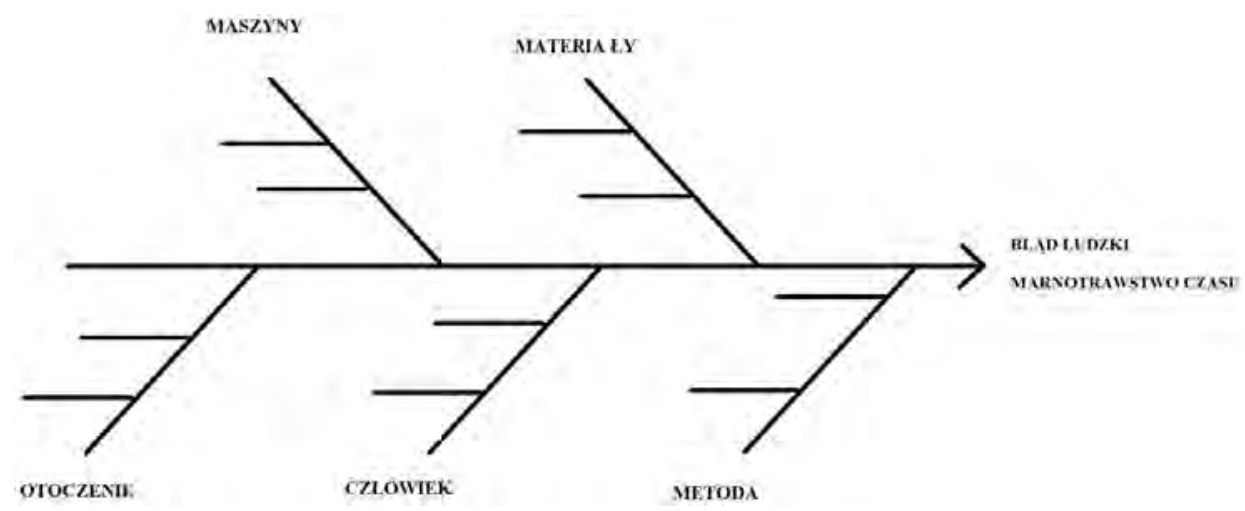

Rysunek 1. Diagram Ishikawy Źródto: opracowanie własne.

\section{Kwantyfikacja procesu, czyli MTM}

Methods Time Measurement (w skrócie MTM) należy rozumieć jako metodę rozkładającą analizowany proces na ruchy podstawowe zwane elementarnymi. Każdy z elementów jest odpowiednio zmierzony, aby mógł posłużyć do analizy. W celu wyodrębnienia poszczególnych ruchów podstawowych i ustalenia czasu niezbędnego do wykonania konkretnej czynności w zakładach produkcyjnych sfilmowano liczne przebiegi pracy. Na podstawie materiału wideo wyliczono liczbę klatek na jeden ruch (prędkość filmu 16 zdjęć na sekundę) i tym samym ustalono czas rzeczywisty czynności. 
Methods Time Measurement jest jednym ze sposobów normalizacji i standaryzacji procesów. Poziom konkurencyjności przedsiębiorstwa na rynku zależy od kilku wielkości:

- kosztów,

- personelu,

- jakości,

- rynku,

- czasu.

Można powiedzieć, że czas zajmuje najważniejszą pozycję, gdyż ma bezpośredni wpływ na wartości pozostałych wielkości. W umiejętnym gospodarowaniu czasem wymaga się uzyskania wysokiego współczynnika zwymiarowania ważnych procesów przedsiębiorstwa. Samo pozyskanie pomiarów powinno służyć do analizy i odpowiedniej interpretacji, musimy jednak pamiętać, że w centrum zainteresowania winien się znaleźć sam kształt procesu, a nie jedynie znormowanie jego czasu. Zarządzanie czasem samo w sobie nie wiąże się z rozwojem procesu. Pamiętajmy, że mając wpływ na czas, mamy realny wpływ na jakość naszego produktu, a co za tym idzie, wpływamy na konkurencyjność przedsiębiorstwa.

Metoda korzysta z własnej jednostki czasu, która została określona jako $1 \mathrm{TMU}^{1}=1 / 100000$ godziny.

Tabela 1. Przeliczenie podstawowych jednostek czasu na jednostkę stosowaną w metodzie MTM

\begin{tabular}{|c|c|c|c|}
\hline \multirow{2}{*}{ TMU } & \multicolumn{3}{|c|}{ Jednostki czasu } \\
\cline { 2 - 4 } & Sekundy & Minuty & Godziny \\
\hline 1 & 0,036 & 0,0006 & 0,00001 \\
\hline 27,8 & 1 & - & - \\
\hline 1666,7 & - & 1 & - \\
\hline 100000 & - & - & 1 \\
\hline
\end{tabular}

Źródło: opracowanie własne.

Stosowanie metody MTM może spełniać różne funkcje, jak:

- kształtowanie metod pracy - wypracowywanie metod pracy lub ich doskonalenie,

- pomiar czasu - ustalenia czasu „założonego” do wynagrodzenia,

- instruktaż - tworzenie podstawy opisu metody pracy.

MTM może stać się pomocny przy optymalizowaniu systemu pracy. Na etapie planowania należy określić podstawowe cele usprawnienia, jak na przykład redukcja przebiegów nieprzynoszących wartości dodanej. Elementami, które można poddać analizie, są:

1 TMU jest skrótem od Time Measurement Unit i oznacza ,jednostka - miara czasu”. 
- przebieg ruchu,

- struktura pracy,

- przepływ materiału.

Dzięki przeprowadzonej analizie przed rozpoczęciem pracy można dokładnie ustalić sposób pracy oraz czas jej wykonania. Wykonanie analizy jest możliwe wyłącznie w oparciu o przyjęte standardy, co pozwoli na wyeliminowanie dużej części błędów w procesie. Standardy powinny być tak opracowane, aby nie były zbyt obszerne i jednocześnie pozwalały na dokładne odtworzenie procesu, czyli powinny być przejrzyste, łatwe do nauczenia się i stosowania.

Składową wpływającą na jakość procesu jest metoda pracy, która z kolei uwarunkowana jest sprawnością wykonującego. Przez sprawność rozumiemy zdolność do wykonywania ruchów nabytą podczas realizowania zadań roboczych, zależną od umiejętności, a także doświadczenia i wprawy. Czas wykonywania zadania będzie zmniejszał się wraz ze wzrostem liczby powtórzeń. Jeśli weźmiemy pod uwagę ruchy, które wymagają dużej wprawy wykonującego, a także takie, które takiej wprawy nie wymagają, wówczas możemy zauważyć, że poziom wprawy nie zależy od prędkości ruchu, lecz przede wszystkim od stosowanej metody pracy. Nowo poznana operacja wymaga na początku większej liczby ruchów niż operacja znana.

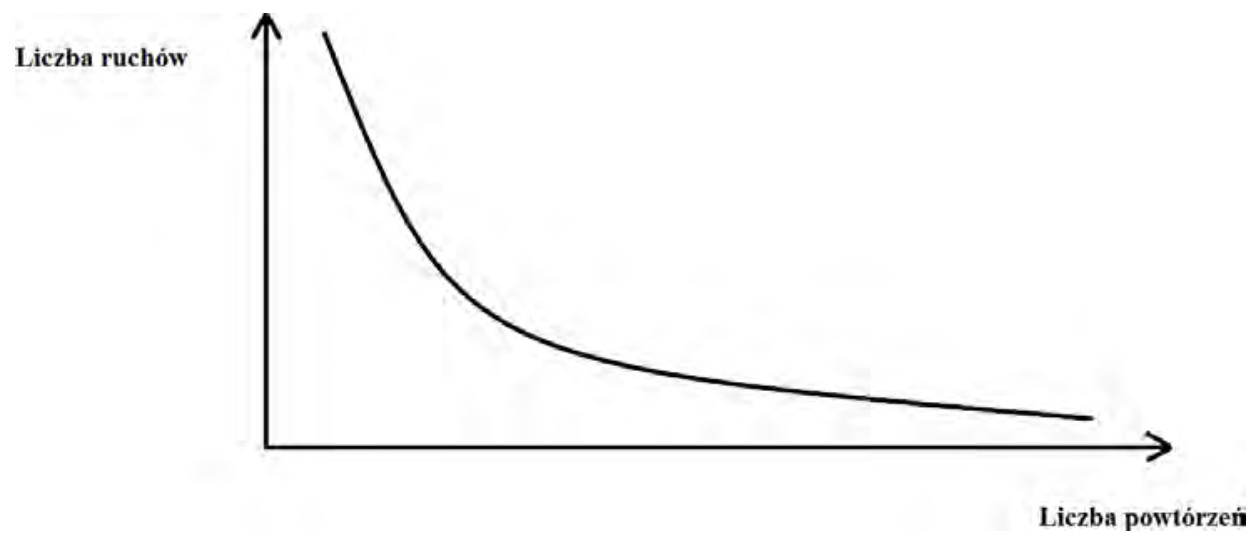

Rysunek 2. Wykres liczby ruchów zestawiony z liczbą możliwych do uzyskania powtórzeń

Źródto: opracowanie własne.

Nowo wprowadzona operacja bez dostatecznej ilości ćwiczeń składa się z szeregu nieporadnych ruchów, ruchów pomocniczych i funkcji wzrokowych, które to przekładają się na wydłużenie czasu obsługi danej czynności. Ćwiczenia „stanowiskowe" przyczyniają się do poprawienia koordynacji ruchów, zmniejszają nakład kontroli niezbędnej do wykonania ruchu. Konsekwencją wykonywanych ćwiczeń jest wypracowanie metody pracy. 
Punktem wyjścia do analizy dowolnego przebiegu ruchu jest rozgraniczenie dwóch pojęć: metody pracy i sposobu pracy. Aby zrozumieć te dwa pojęcia, należy zadać sobie pytanie „Co?” - otrzymamy w ten sposób opis metody pracy, zawierający zasady wykonywania przebiegów roboczych człowieka. Drugim pytaniem, które należy zadać, jest pytanie „Jak dobrze?” - w odpowiedzi na nie uzyskamy opis sposobu pracy, tym samym opisany zostanie indywidualny sposób wykonania przebiegu podanego w metodzie pracy.

\section{Przegląd ruchów elementarnych MTM}

System analityczny MTM ma na celu opis i kwantyfikację ruchów wykonywanych przez człowieka. Regułą kształtowania optymalnej metody pracy jest wykonanie zadania z jak najmniejszą liczbą ruchów przy możliwie najmniejszej czasochłonności procesu.

Na potrzeby metody zwartościowano czasy normatywne 17 ruchów podstawowych, z których wykorzystuje się głównie 5 ruchów. MTM zapożycza swoje metody do innych analiz, takich jak UAS (Uniwersalny System Analityczny). Rozbudowanie systemu daje szanse na bardziej kompleksową ocenę przebiegu pracy, wiąże się to natomiast ze spadkiem precyzji systemu.
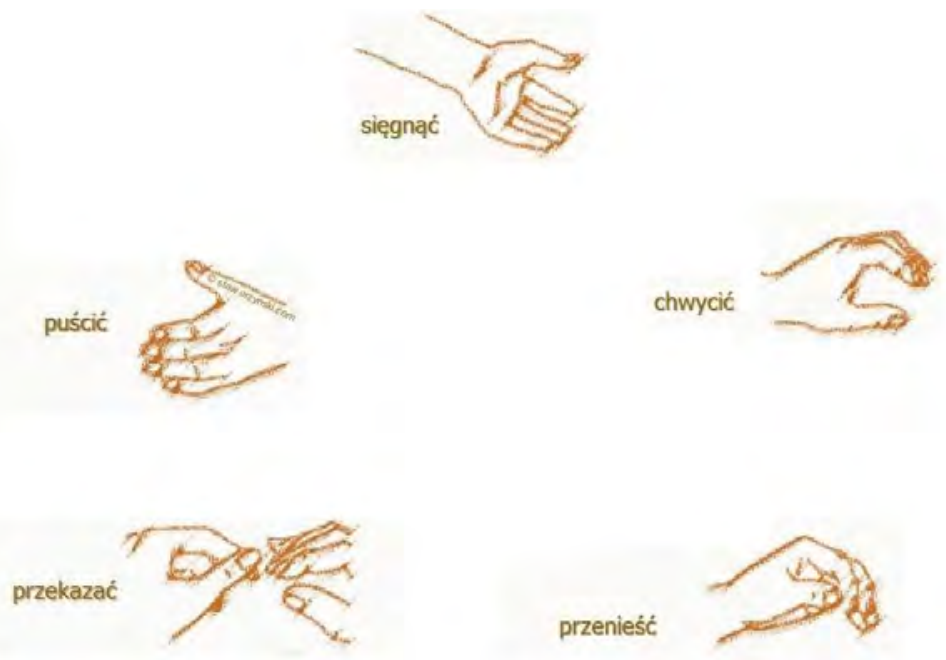

Rysunek 3. Cykl ruchów elementarnych

Źródło: opracowanie własne na podstawie http://www.staworzynski.com/sites/default/files/ ctools/ekonomika_ruchow_elementarnych.jpg [dostęp 1.03.2016]. 
Istotą systemu MTM jest rozłożenie elementów procesu na szczegółowe jednostki ruchu. Najczęściej wykorzystywane ruchy w trakcie przebiegu procesu to:

a) reach (pol. sięgać) - należy rozumieć jako ruch elementarny palców lub ręki do określonego lub nieokreślonego miejsca.

Wielkościami wpływającymi na efektywność tego ruchu są:

- długość ruchu - jest to rzeczywiście pokonana droga między punktem początkowym i końcowym, mierzona w centymetrach. Wartość czasu dla długości powyżej $80 \mathrm{~cm}$ uzyskuje się przez ekstrapolację. Ekstrapoluje się w przedziałach odległości co $5 \mathrm{~cm}$. Jeśli długość ruchów rąk zostanie skrócona dzięki pomocy innych części ciała, to skrócenie trzeba odjąć od całej długości ruchu.

- przypadek ruchu - jest to wielkość pokazująca stopień koniecznej kontroli operatora procesu. Im wyższy stopień kontroli, tym więcej uwagi wymaga się od pracownika dla uzyskania tego samego efektu, przez co wydłuża się jednostkowy czas procesu.

- typ przebiegu ruchu - różnicuje poszczególne „podprocesy” na te, które posiadają chwilowe przyspieszenie lub opóźnienie.

b) grasp (pol. chwytać) - należy rozumieć jako ruch ręki lub palców w celu uzyskania kontroli nad przedmiotem lub przedmiotami, w takim stopniu, aby możliwe było wykonanie kolejnego ruchu elementarnego (ma zapewnić stabilny uchwyt).

Wielkościami wpływającymi na efektywność chwytania są:

- sposób chwytania - jest uzależniony od metody przejęcia kontroli nad przedmiotem. Wyróżniamy sposoby chwytania o niskim, średnim i wysokim nakładzie kontroli, którym przyporządkowuje się różne wartości czasu.

Np. chwyt wybiórczy wymieszanych przedmiotów zajmuje czterokrotnie więcej czasu niż chwycenie oddzielnie leżących przedmiotów.

- położenie przedmiotu - dla sposobu wykonywania pracy bardzo ważna jest ergonomiczna odległość, jak i ułożenie. Po wykroczeniu poza założoną normę dla danej czynności spada efektywność wykonywania procesu (może dziać się to także przy zbyt bliskiej odległości, która będzie wymagała dodatkowego ruchu, jak np. cofanie się).

- właściwości przedmiotu - gabaryty oraz inne właściwości fizyczne materiału obsługiwanego w czasie procesu wpływają na dobór metody chwytania.

c) move (pol. przenieść) - należy rozumieć jako ruch elementarny jednego lub więcej elementów przy użyciu palców lub ręki do miejsca jego przeznaczenia. 
Wielkości wpływające na efektywność przeniesienia:

- długość ruchu - jest to rzeczywiście pokonana droga między punktem początkowym i końcowym, która mierzona jest w centymetrach.

- przypadek ruchu - jest to wielkość pokazująca stopień koniecznej kontroli operatora procesu. Im wyższy stopień kontroli, tym więcej uwagi wymaga się od pracownika dla uzyskania tego samego efektu, przez co wydłuża się jednostkowy czas procesu.

- typ przebiegu ruchu - różnicuje poszczególne „podprocesy” na te, które posiadają chwilowe przyspieszenie lub opóźnienie.

- nakład siły - jest uzależniony od ciężaru przedmiotu, który opóźnia ruch przeniesienia (obojętne czy przedmiot jest niesiony, suwany, ciągniony).

d) position (pol. umieszczać) - należy rozumieć jako ruch palców lub ręki, aby dwa przedmioty wsunąć jeden w drugi lub razem zetknąć.

Wyróżniamy dwa sposoby ruchu łączenia:

- włożenie - jeden przedmiot wkłada się do drugiego (wsuwamy lub wstawiamy) - które z kolei dzieli się na trzy następujące po sobie fazy:

i. centrowanie, czyli przygotowanie do włożenia, mające na celu znalezienie wspólnej osi połączeń,

ii. wyrównanie, czyli obracanie przedmiotów wokół osi łączenia w celu uzyskania pokrycia przekrojów,

iii. wciśnięcie, czyli przedmioty wkładane są jeden w drugi.

Wielkościami wpływającymi na efektywność włożenia jest klasa pasowania (luźne, suwliwe, ciasne).

- Przyłożenie - jeden przedmiot przykłada się do drugiego (zetknięcie, przystawienie lub dołożenie).

Przyłożenie dzieli się na trzy następujące po sobie fazy:

i. Centrowanie - czyli przygotowanie do przyłożenia, mające na celu znalezienie wspólnej osi połączeń.

ii. Wyrównanie - czyli obracanie przedmiotów wokół osi łączenia w celu uzyskania pokrycia przekrojów.

iii. Dołączenie - czyli jeden przedmiot jest styczny z drugim zgodnie z założeniami projektowymi.

e) release (pol. puszczać) - należy rozumieć jako ruch podstawowy, wykonywany, gdy palce lub ręka tracą kontrolę nad przedmiotem.

Wielkością wpływającą na efektywność puszczania jest:

- Przypadek ruchu:

i. Puszczenie przedmiotu poprzez rozwarcie palców.

ii. Puszczanie przez utratę kontaktu bez ruchów palca. 


\section{Największe korzyści z wdrożenia i korzystania z MTM w przedsiębiorstwie}

Dzięki zastosowaniu metody MTM zyskujemy możliwość szczegółowego ustalenia metody pracy i czasu jej trwania, jest to możliwe także przed rozpoczęciem pracy, nawet czynności wykonywanej po raz pierwszy.

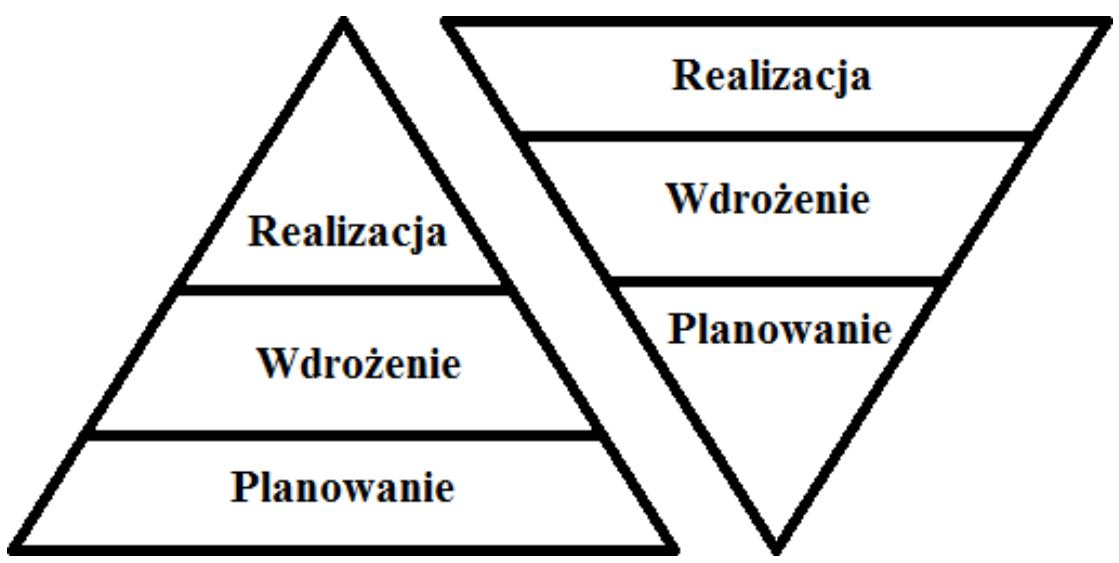

Rysunek 4. Odwrócone trójkąty pokazujące korzyści z dobrego planowania Źródło: opracowanie własne.

Zgodnie z zasadami dobrego planowania możemy zredukować koszty jednostkowe produkcji poprzez wcześniejsze optymalne projektowanie przebiegu procesu, zamiast optymalizacji działającego już organizmu. Przy wykorzystaniu metody MTM zyskujemy bardziej miarodajną ocenę tempa pracy, co przekłada się na lepsze możliwości zarządzania i gratyfikowania pracy kadry robotniczej. Poziom standaryzacji pracy w systemie korzystającym z MTM zakłada możliwość szkolenia stanowiskowego jeszcze przed rozpoczęciem właściwej obsługi procesu, co pozwala na zmniejszenie czasu przyuczania do minimum. Wykorzystanie metody pomiaru czasu jest uniwersalne z punktu widzenia używania wspólnego języka, który jest standardem systemu. Na sukces metody składa się konieczność optymalizacji kosztów i produktywności już w fazie tworzenia czy projektowania procesu. MTM doskonale wpisuje się w ten trend, gdyż pozwala kwantyfikować i porównywać wartości normatywne w łatwy sposób. 


\section{Podsumowanie}

Każde przedsiębiorstwo dla sprawnego i zrozumiałego zarządzania danymi i czasem potrzebuje odpowiedniego modelu planowania i metod pracy. Istniejące otoczenie i stawiane przez nie wymagania sprawiają, że sposoby zarządzania muszą być zróżnicowane. Opracowane przez Toyotę zasady zarządzania to $5 \mathrm{~S}$ :

- 1S - seiri (pol. selekcja) - rozumiana jako eliminacja zbędnych materiałów na stanowisku pracy.

- $2 S$ - seiton (pol. systematyka) - rozumiana jako organizacja miejsca pracy.

- 3S - seiso (pol. sprzątanie) - rozumiane jako porządkowanie miejsca pracy, a także organizacja środków czystości.

- 4S - seiketsu (pol. standaryzacja) - rozumiana jako zapewnienie stałego miejsca do przechowywania rzeczy na stanowisku pracy.

- 5S - shitsuke (pol. samodyscyplina) - rozumiana jako wyrobienie nawyku do przestrzegania i realizacji czterech powyższych zasad.

MTM opiera się na przedstawionych wyżej zasadach, przekazuje praktyczne zastosowanie technik pomiaru czasu w takich obszarach, jak: kształtowanie produktów i środków pracy, ergonomiczne kształtowanie systemów pracy oraz ciągły proces ulepszania procesów w różnych obszarach przedsiębiorstwa. Pomiary czasu pracy są bardzo istotnym elementem z uwagi na nowoczesne systemy symulacji komputerowych, dające możliwości odwzorowania sposobu pracy i jego wizualizacji. MTM może być pomocny przy planowaniu liczby linii produkcyjnych, a konkretnie do zdefiniowania jej przepustowości. Często niewydolnie zaplanowany proces będzie wąskim gardłem dla całego systemu, wszelkiego rodzaju kwantyfikowalne wartości są istotne z poziomu wykonywanej symulacji i projektu przepływu materiału. Metodę MTM możemy zastosować we wszystkich sektorach przemysłu. Zaletą jej standaryzacji jest łatwość $\mathrm{w}$ przyswojeniu i interpretacji. Czas wykonywania operacji zależy od wybranej metody. Metoda winna być stosowana na całym świecie według jednolitych standardów.

Dodatkowym atutem metody jest miarodajność, gdyż do analizy tempa pracy brana jest pod uwagę wydajność wzorcowa, czyli tempo średnio wprawionego człowieka, które potrafi on utrzymać bez zmęczenia.

\section{Bibliografia}

Bednarek M., (2007), Doskonalenie systemów zarządzania. Nowa droga do przedsiębiorstwa Lean, Centrum Doradztwa i Informacji Difin, Warszawa. 
Detyna B., (2011), Zarzq̨dzanie jakościq w logistyce. Metody i narzędzia wspomagające. Przykłady i zadania, Państwowa Wyższa Szkoła Zawodowa im. Angelusa Silesiusa w Wałbrzychu, Wałbrzych.

Ejdys J., Kobylińska U., Lulewicz-Sas A., (2012), Zintegrowane systemy zarządzania jakością, środowiskiem i bezpieczeństwem pracy, Oficyna Wydawnicza Politechniki Białostockiej, Białystok.

Kończak G., (2007), Metody statystyczne w sterowaniu jakością produkcji, Wydawnictwo Akademii Ekonomicznej w Katowicach, Katowice.

Ładoński W., Szołtysek K. (red.), (2008), Zarzq̨dzanie jakościq̨. Część 3. Metody kształtowania jakości organizacji, Wydawnictwo Uniwersytetu Ekonomicznego we Wrocławiu, Wrocław.

Niemczyk A., (2013), Organizacja i monitorowanie procesów magazynowych, Instytut Logistyki i Magazynowania, Poznań.

Salerno-Kochan M. (red.), (2005), Wyzwania zarządzania jakością, Centrum Rozwoju i Promocji Akademii Ekonomicznej w Krakowie, Kraków.

Urbaniak M., (2010), Kierunki doskonalenia systemów zarzq̨dzania jakością, Wydawnictwo Uniwersytetu Łódzkiego, Łódź.

Zamostny B. (red.), (2014), Systemy zarządzania przedsiębiorstwem - techniki Lean Management i Kaizen, Wydawnictwo Wiedza i Praktyka, Warszawa.

\section{Źródta internetowe}

http://www.staworzynski.com/artykuly/ekonomika-ruchow-elementarnych-mtm [dostęp 1.03.2016]. 